Article

\title{
Characterization of a Novel Nicotine Hydroxylase from Pseudomonas sp. ZZ-5 That Catalyzes the Conversion of 6-Hydroxy-3-Succinoylpyridine into 2,5-Dihydroxypyridine
}

\author{
Tao Wei ${ }^{1}$, Jie Zang ${ }^{1}$, Yadong Zheng ${ }^{1}$, Hongzhi Tang ${ }^{2}$, Sheng Huang ${ }^{1}$ and Duobin Mao ${ }^{1, *}$ \\ 1 School of Food and Biological Engineering, Zhengzhou University of Light Industry, Zhengzhou 450002, \\ China; weit8008@zzuli.edu.cn (T.W.); zangjie@163.com (J.Z.); Zhengyd@163.com (Y.Z.); \\ Huangshen@126.com (S.H.) \\ 2 State Key Laboratory of Microbial Metabolism, School of Life Sciences and Biotechnology, \\ Shanghai Jiao Tong University, Shanghai 200240, China; Tanghz@126.com \\ * Correspondence: duobinmao@126.com; Tel.: +86-371-86609631; Fax: +86-371-86609631
}

Received: 11 August 2017; Accepted: 26 August 2017; Published: 31 August 2017

\begin{abstract}
A novel nicotine hydroxylase was isolated from Pseudomonas sp. ZZ-5 (HSPHZZ). The sequence encoding the enzyme was 1206 nucleotides long, and encoded a protein of 401 amino acids. Recombinant $\mathrm{HSPH}_{\mathrm{ZZ}}$ was functionally overexpressed in Escherichia coli BL21-Codon Plus (DE3)-RIL cells and purified to homogeneity after Ni-NTA affinity chromatography. Liquid chromatography-mass spectrometry (LC-MS) analyses indicated that the enzyme could efficiently catalyze the conversion of 6-hydroxy-3-succinoylpyridine (HSP) into 2,5-dihydroxypyridine (2,5-DHP) and succinic acid in the presence of nicotinamide adenine dinucleotide (NADH) and flavin adenine dinucleotide (FAD). The kinetic constants $\left(\mathrm{K}_{m}, \mathrm{k}_{\text {cat }}\right.$, and $\mathrm{k}_{\text {cat }} / \mathrm{K}_{m}$ ) of $\mathrm{HSPH}_{\mathrm{ZZ}}$ toward HSP were $0.18 \mathrm{mM}, 2.1 \mathrm{~s}^{-1}$, and $11.7 \mathrm{~s}^{-1} \mathrm{mM}^{-1}$, respectively. The optimum temperature, $\mathrm{pH}$, and optimum concentrations of substrate and enzyme for 2,5-DHP production were $30^{\circ} \mathrm{C}, 8.5,1.0 \mathrm{mM}$, and $1.0 \mu \mathrm{M}$, respectively. Under optimum conditions, $85.3 \mathrm{mg} / \mathrm{L}$ 2,5-DHP was produced in $40 \mathrm{~min}$ with a conversion of $74.9 \%$. These results demonstrated that $\mathrm{HSPH}_{\mathrm{ZZ}}$ could be used for the enzymatic production of 2,5-DHP in biotechnology applications.
\end{abstract}

Keywords: HSP; 2,5-DHP; Pseudomonas; HSP hydroxylase; gene cloning

\section{Introduction}

Nicotine is the principal alkaloid in tobacco plants, and is responsible for smoking addiction and several diseases such as cancer and pulmonary disease [1-3]. The manufacturing of tobacco products and all activities involving tobacco produce large amounts of solid or liquid waste with a high nicotine content. Therefore, nicotine is the primary toxic substance in tobacco wastes $[3,4]$. These wastes have been designated as "toxic and hazardous wastes" under European Union Regulations [5]. Since tobacco waste is a major problem for public health and the environment, it is important to establish appropriate detoxification methods. Microbial degradation of nicotine provides a method to treat such wastes [6,7]. Several microorganisms have been found to degrade nicotine, including Arthrobacter, Pseudomonas, Agrobacterium tumefaciens S33, Aspergillus oryzae, Sphingomonas sp., Acinetobacter sp., Shinella sp. strain HZN7, Rhodococcus sp., and Cellulomonas sp. [3,8-14].

Recent studies have reported methods to synthesize chemicals of pharmaceutical importance from nicotine, such as (S)-macrostomine, nicotinonitrile, and fused-ring nicotine derivatives [15-18]. Dihydropyridines are important precursors in medicinal chemistry, and have been used to produce compounds with antitumor activity for cancer therapy, antidiabetic agents to treat 
vascular disorders, and HIV protease inhibitors [19-22]. However, the lack of efficient methods to synthesize 2,5-dihydropyridine has restricted studies on its biological activity and applications [18]. The traditional chemical method to produce 2,5-dihydropyridine (2,5-DHP) is complex, creates hazardous byproducts, and has potentially undesirable side reactions and a high energy cost. Therefore, the enzymatic synthesis of 2,5-dihydropyridine represents an attractive alternative to chemical synthesis, because of its high specificity, high efficiency, and low production of pollutants.

In this study, a novel HSP (6-hydroxy-3-succinoylpyridine) hydroxylase was purified from Pseudomonas sp. ZZ-5 ( $\left.\mathrm{HSPH}_{\mathrm{ZZ}}\right)$, and then its encoding gene was cloned and expressed in bacterial cells. The recombinant $\mathrm{HSPH}_{\mathrm{ZZ}}$ exhibited high activity to convert HSP to 2,5-DHP. The optimum concentrations of substrate and enzyme for the formation of 2,5-DHP were determined, and the kinetic parameters and catalytic properties of the recombinant $\mathrm{HSPH}_{\mathrm{ZZ}}$ were characterized.

\section{Results and Discussion}

\subsection{Purification and Identification of $\mathrm{HSPH}_{\mathrm{ZZ}}$}

The $\mathrm{HSPH}_{\mathrm{ZZ}}$ with HSP hydroxylase activity was purified to homogeneity from cells of Pseudomonas sp. ZZ-5 using the steps shown in Table 1. The enzyme was purified 17.6-fold to give a yield of $13.4 \%$ and a specific activity of $5.1 \mathrm{U} / \mathrm{mg}$. The molecular mass of the purified enzyme was estimated to be $45 \mathrm{kDa}$ by SDS-PAGE (Figure 1), similar to that of HSP hydroxylases from Pseudomonas putida S16 and Agrobacterium tumefaciens S33 [23,24].

Table 1. Purification of a novel HSP (6-hydroxy-3-succinoylpyridine) hydroxylase from Pseudomonas sp. $\mathrm{ZZ}-5\left(\mathrm{HSPH}_{\mathrm{ZZ}}\right)$.

\begin{tabular}{|c|c|c|c|c|c|}
\hline Step & Total Protein (mg) & Total Activity (U) & Specific Activity (U/mg) & Fold & Yield (\%) \\
\hline Crude cell extract & 672.6 & 195.4 & 0.29 & 1 & 100 \\
\hline$\left(\mathrm{NH}_{4}\right)_{2} \mathrm{SO}_{4}$ precipitation & 542.3 & 173.5 & 0.31 & 1.1 & 88.8 \\
\hline DEAE sepharose & 75.2 & 100.3 & 1.3 & 4.6 & 51.3 \\
\hline Phenyl sepharose & 22.3 & 54.5 & 2.4 & 8.4 & 27.8 \\
\hline Superdex-200 & 5.1 & 26.1 & 5.1 & 17.6 & 13.4 \\
\hline
\end{tabular}

Values given are the average of three replications.

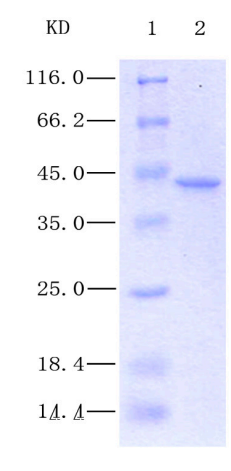

A

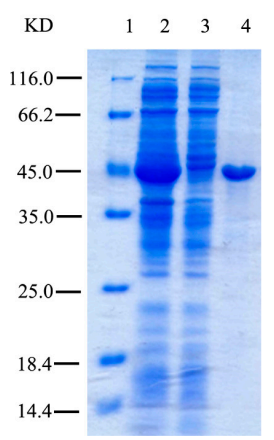

B

Figure 1. (A) SDS-PAGE of the purified native $\mathrm{HSPH}_{\mathrm{ZZ}}$ from Pseudomonas sp. ZZ-5. Lane 1, molecular weight standards; Lane 2, superdex-200 gel filtration chromatography product (purified enzyme); (B) SDS-PAGE of the purified recombinant $\mathrm{HSPH}_{\mathrm{ZZ}}$ from Pseudomonas sp. ZZ-5. Lane 1, molecular weight standards; Lane 2, crude cell extract; Lane 3, supernatant after centrifugation; Lane 4, supernatant after centrifugation; $\mathrm{HSPH}_{\mathrm{ZZ}}$ after nickel affinity chromatography. 
To identify the reaction catalyzed by the purified enzyme, the products of the $\mathrm{HSPH}_{\mathrm{ZZ}}$ oxidation reaction were analyzed by liquid chromatography-mass spectrometry (LC-MS). The analyses of the reaction products revealed $m / z$ values of 110.0,117.1, and 194.0, which corresponded to the calculated molecular mass of 2,5-DHP $\left(\mathrm{C}_{5} \mathrm{H}_{5} \mathrm{NO}_{2}, 111.10\right)$, succinic acid $\left(\mathrm{C}_{4} \mathrm{H}_{6} \mathrm{O}_{4}, 118.09\right)$, and $\mathrm{HSP}\left(\mathrm{C}_{9} \mathrm{H}_{9} \mathrm{NO}_{4}\right.$, 195.17), respectively (Supplementary Figure S1). These results demonstrated that $\mathrm{HSPH}_{\mathrm{ZZ}}$ has high HSP hydroxylase activity to convert HSP to 2,5-DHP and succinic acid (Figure 2). To our knowledge, $\mathrm{HSPH}_{\mathrm{ZZ}}$ is only the second example of an HSP hydroxylase from Pseudomonas to-date.

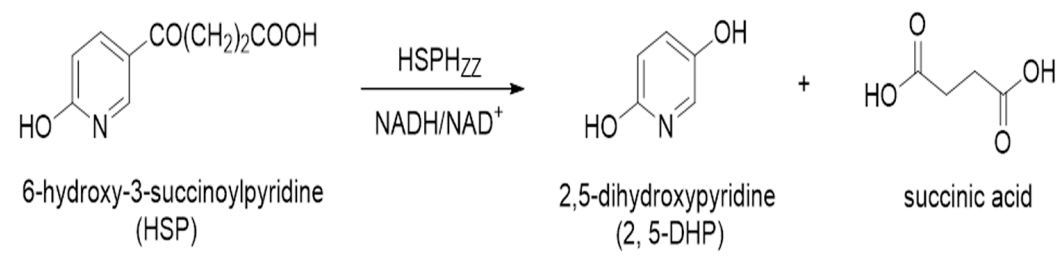

Figure 2. Enzymatic production of 2,5-dihydroxypyridine (2,5-DHP) from HSP catalyzed by the nicotine hydroxylase $\mathrm{HSPH}_{\mathrm{Zz}}$.

\subsection{Gene Cloning and Sequence Analysis of $\mathrm{HSPH}_{\mathrm{ZZ}}$}

The N-terminal amino acid sequence of purified $\mathrm{HSPH}_{\mathrm{ZZ}}$ was determined to be M-S-G-H-L-R-V-I-I-I-V-G-G-G-P by the automated Edman degradation technique. The DNA fragment encoding $\mathrm{HSPH}_{\mathrm{ZZ}}$ was directly amplified by PCR using the genomic DNA of Pseudomonas sp. ZZ-5 as the template. The $\mathrm{HSPH}_{\mathrm{ZZ}}$ sequence (1206 bp) was found to encode a $44.3 \mathrm{kDa}$ protein composed of 401 amino acids. The amino acid sequence of $\mathrm{HSPH}_{\mathrm{ZZ}}$ showed high identity with HSPHs from P. putida S16 (Accession No. WP_013973865.1, 86\% identity), Pseudomonas sp. JY-Q (Accession No. WP_064613869.1, 85\% identity), Pseudomonas sp. EGD-AK9 (Accession No. WP_031302470.1, 83\% identity), and A. tumefaciens (Accession No. WP_031302470.1, 60\% identity), respectively. Multiple sequence alignment analyses revealed that $\mathrm{HSPH}_{\mathrm{ZZ}}$ contained the conserved motif Gly-Ala-Glu-Gly-Ala (amino acids 166-170), which is associated with FAD- and NAD(P)H-binding [25] (Supplementary Figure S2). At the amino acid sequence level, $\mathrm{HSPH}_{\mathrm{ZZ}}$ also showed high identity to p-nitrophenol monooxygenases from Acidovorax sp. NO-1 (58\%), Sphingomonas melonis TY (52\%), and Massilia putida (43\%). However, $\mathrm{HSPH}_{\mathrm{ZZ}}$ did not show any detectable activity with p-nitrophenol as the substrate (data not shown).

\subsection{Expression of Recombinant $\mathrm{HSPH}_{\mathrm{ZZ}}$ in Escherichia coli BL21-Codon Plus (DE3)-RIL}

The recombinant plasmid $\mathrm{pET} 22 \mathrm{~b}-\mathrm{HSPH} \mathrm{ZZ}_{\mathrm{Z}}$ was constructed to determine the catalytic properties of recombinant $\mathrm{HSPH}_{Z Z}$. The recombinant $\mathrm{HSPH}_{Z Z}$ was expressed in E. coli BL21-Codon Plus (DE3)-RIL cells and purified to homogeneity after Ni-NTA affinity and Superdex 200 gel filtration chromatography. The purified recombinant $\mathrm{HSPH}_{\mathrm{ZZ}}$ with a polyhistidine $(6 \times \mathrm{His})$ tag at the $\mathrm{C}$ terminus was visible as a major band with a calculated mass of $45 \mathrm{kDa}$ in SDS-PAGE analyses (Figure 1). The specific activity of the purified recombinant $\mathrm{HSPH}_{\mathrm{ZZ}}$ was $31.8 \mathrm{U} / \mathrm{mg}-6.2$-fold that of the HSPH isolated from the original strain Pseudomonas sp. ZZ-5 (Supplementary Table S1).

\subsection{Effect of Temperature and $p H$ on Activity of the Recombinant $H S P H_{Z Z}$}

The effects of $\mathrm{pH}(5.5-10)$ and temperature $\left(5-45^{\circ} \mathrm{C}\right)$ on the hydroxylase activity of the recombinant $\mathrm{HSPH}_{\mathrm{ZZ}}$ were determined using the standard enzyme assay. The optimum temperature and $\mathrm{pH}$ of $\mathrm{HSPH}_{\mathrm{ZZ}}$ were determined to be $30^{\circ} \mathrm{C}$ and 8.5, respectively (Figure 3). The $\mathrm{pH}$ optimum was higher than that of reported HSP hydroxylases from P. putida S16 and A. tumefaciens S33 (pH 8.0) [23,24]. The thermostability of $\mathrm{HSPH}_{\mathrm{ZZ}}$ was evaluated at three different temperatures $\left(30^{\circ} \mathrm{C}, 35^{\circ} \mathrm{C}\right.$, and $\left.40{ }^{\circ} \mathrm{C}\right)$ with increasing incubation times up to $120 \mathrm{~min}$. Most of the enzyme activity was maintained after incubation at $30{ }^{\circ} \mathrm{C}$ for at least $120 \mathrm{~min}$, whereas incubation at $40{ }^{\circ} \mathrm{C}$ for $30 \mathrm{~min}$ reduced to 
approximately $40 \%$ of the maximum activity. The $\mathrm{pH}$ stability of $\mathrm{HSPH}_{\mathrm{ZZ}}$ was determined at $\mathrm{pHs}$ ranging from 5.5 to 10.0 , and the results demonstrated that over $50 \%$ of its maximal activity was maintained from pH 7.0 to 9.0 (Supplementary Figure S3).

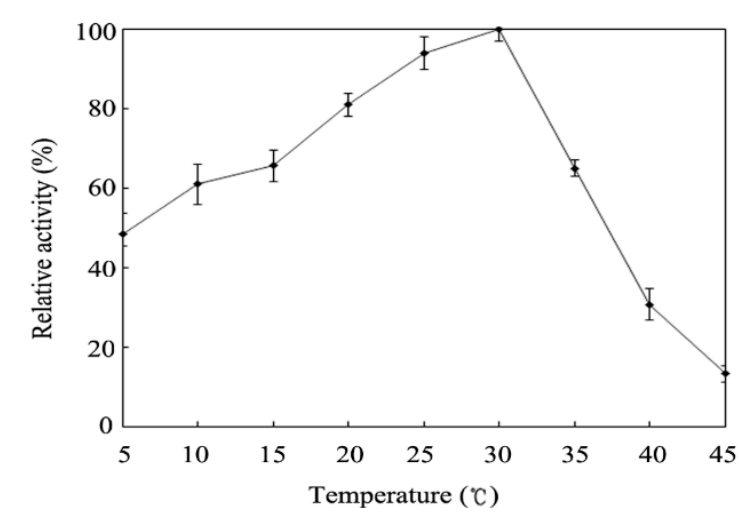

A

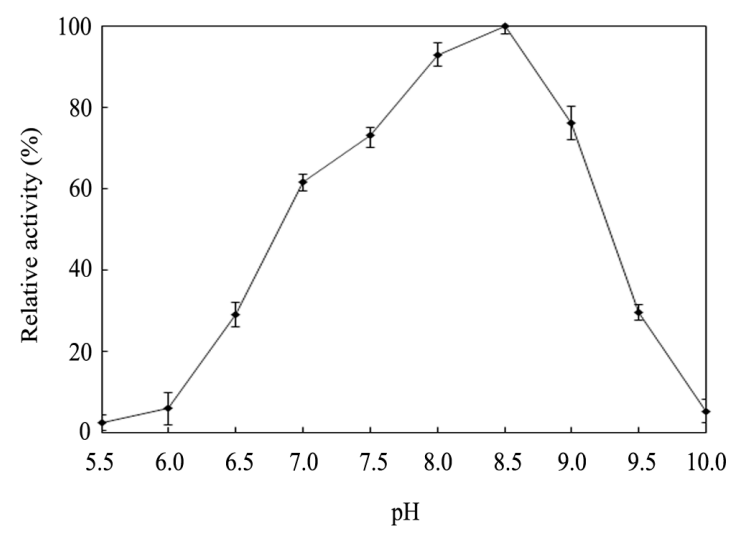

B

Figure 3. Temperature and $\mathrm{pH}$ optima of the nicotine hydroxylase $\mathrm{HSPH}_{\mathrm{ZZ}}$. (A) Temperature optimum of $\mathrm{HSPH}_{\mathrm{ZZ}}$ was determined with HSP as substrates in $20 \mathrm{mM}$ Tris- $\mathrm{HCl}$ buffer ( $\mathrm{pH} 8.5$ ) at temperatures ranging from $5{ }^{\circ} \mathrm{C}$ to $45^{\circ} \mathrm{C}$; (B) $\mathrm{pH}$ optimum of the enzyme at $\mathrm{pHs}$ ranging from 5.5 to 10 was measured for $30 \mathrm{~min}$ at $30^{\circ} \mathrm{C}$. The buffers used were $20 \mathrm{mM}$ of sodium acetate (pH 5.5 to 6.0), sodium phosphate (pH 6.5 to 7.5), Tris- $\mathrm{HCl}$ (pH 8.0 to 9.0), and $\mathrm{N}$-cyclohexyl-3-aminopropanesulfonic acid (pH 9.5 to 10.0). Relative activity was calculated by defining original activity as $100 \%$. The values are means of three independent experiments.

\subsection{Effect of Enzyme and Substrate Concentration on 2,5-DHP Production}

As shown Figure 4, the effects of enzyme $(0.2-2.0 \mu \mathrm{M})$ and substrate concentration $(0.25-2.0 \mathrm{mM})$ on 2,5-DHP production were investigated. In a reaction system containing $1.0 \mathrm{mM} \mathrm{HSP}$, the production of 2,5-DHP increased with increasing enzyme concentration from 0.2 to $1.0 \mu \mathrm{M}$, and then reached a plateau at about $1.0 \mu \mathrm{M}$. Thus, $1.0 \mu \mathrm{M}$ was considered to be the optimum enzyme concentration for 2,5-DHP production (Figure 4). The presence of excess enzyme could result in enzyme agglomeration and diffusion problems, which could decrease the reaction efficiency [26]. The maximum production of 2,5-DHP was observed at $1 \mathrm{mM}$ HSP (Figure 4). Any further increase or decrease in the HSP concentration resulted in a decrease in 2,5-DHP production. Thus, increasing the HSP concentration (from 0.25 to $1 \mathrm{mM}$ ) facilitated contact between the enzyme and the substrate in the reaction system [27]. The Michaelis-Menten equation was applied for catalytic kinetic analysis. The kinetic parameters of $\mathrm{HSPH}_{\mathrm{ZZ}}$ for $\mathrm{HSP}$ were calculated under optimal conditions (at $30{ }^{\circ} \mathrm{C}$ and pH 8.5 in $20 \mathrm{mM}$ Tris- $\mathrm{HCl}$ buffer) and a nicotinamide adenine dinucleotide (NADH) concentration of $1.0 \mathrm{mM}$. The $\mathrm{K}_{m}, \mathrm{k}_{\text {cat }}$, and $\mathrm{k}_{\text {cat }} / \mathrm{K}_{m}$ of $\mathrm{HSPH}_{\mathrm{ZZ}}$ for HSP were $0.18 \mathrm{mM}, 2.1 \mathrm{~s}^{-1}$, and $11.7 \mathrm{~s}^{-1} \mathrm{mM}^{-1}$, respectively (Table 2). When the HSP concentration was $1.0 \mathrm{mM}$, the $\mathrm{K}_{m}, \mathrm{k}_{\text {cat }}$, and $\mathrm{k}_{\text {cat }} / \mathrm{K}_{m}$ of $\mathrm{HSPH}_{\mathrm{ZZ}}$ for NADH were $0.23 \mathrm{mM}, 1.3 \mathrm{~s}^{-1}$, and $5.7 \mathrm{~s}^{-1} \mathrm{mM}^{-1}$, respectively (Table 2).

Table 2. Kinetic parameters of $\mathrm{HSPH}_{\mathrm{ZZ}}$ for the substrate of $\mathrm{HSP}$ or $\mathrm{NADH}{ }^{\mathrm{a}}$.

\begin{tabular}{cccc}
\hline Substrate & $\mathbf{k}_{\text {cat }}\left(\mathbf{s}^{-\mathbf{1}}\right)$ & $\mathbf{K}_{m}(\mathbf{m M})$ & $\mathbf{k}_{\text {cat }} / \mathbf{K}_{m}\left(\mathbf{s}^{-\mathbf{1}} \mathbf{m} \mathbf{M}^{-\mathbf{1}}\right)$ \\
\hline HSP & $2.1 \pm 0.3$ & $0.18 \pm 0.04$ & $11.7 \pm 1.5$ \\
NADH & $1.3 \pm 0.2$ & $0.23 \pm 0.03$ & $5.7 \pm 1.1$ \\
\hline
\end{tabular}

${ }^{\mathrm{a}}$ The values are means of three independent experiments. 


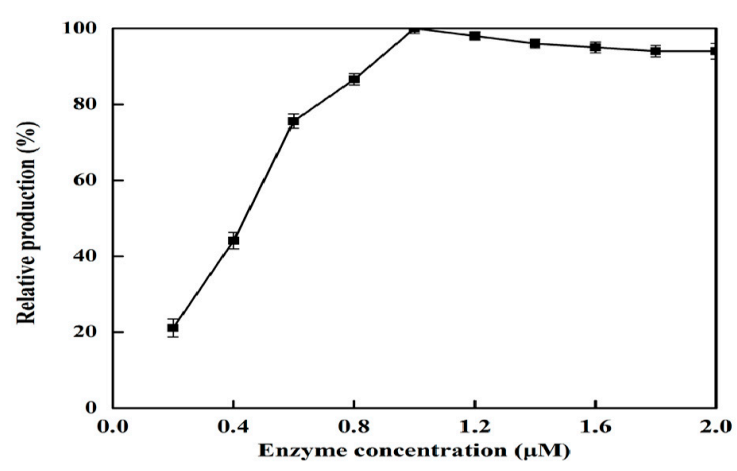

A

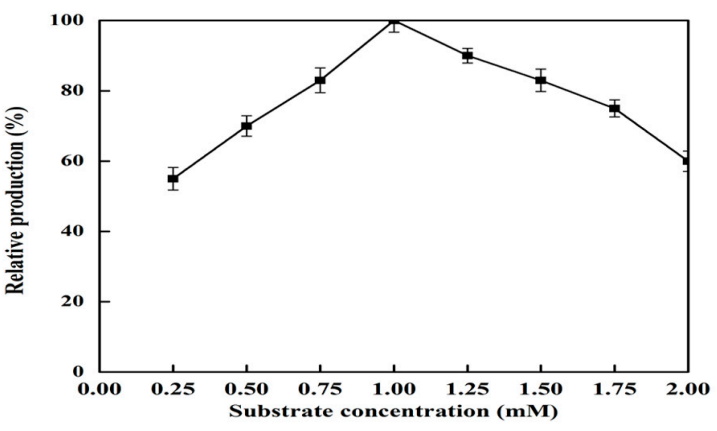

B

Figure 4. (A) Effect of enzyme concentration on the production of 2,5-DHP. The reactions were performed in $20 \mathrm{mM}$ Tris-HCl buffer ( $\mathrm{pH}$ 8.5) containing $10 \mathrm{mM}$ FAD, $1 \mathrm{mM} \mathrm{HSP}$, and $0.5 \mathrm{mM} \mathrm{NADH}$ at $30{ }^{\circ} \mathrm{C}$ for $30 \mathrm{~min}$; (B) Effect of substrate concentration on the production of 2,5-DHP. The reactions were performed in $20 \mathrm{mM}$ Tris-HCl buffer ( $\mathrm{pH}$ 8.5) containing $10 \mathrm{mM} \mathrm{FAD}, 1.0 \mu \mathrm{M}$ enzyme, and $0.5 \mathrm{mM}$ $\mathrm{NADH}$ at $30^{\circ} \mathrm{C}$ for $30 \mathrm{~min}$. The values are means of three independent experiments.

\subsection{Effect of Metal Ions, Organic Solvents, and Detergents on Enzymatic Activity}

The effect various metal ions $\left(\mathrm{Mg}^{2+}, \mathrm{Zn}^{2+}, \mathrm{Cu}^{2+}, \mathrm{Ca}^{2+}, \mathrm{Mn}^{2+}, \mathrm{Ni}^{2+}, \mathrm{Co}^{2+}, \mathrm{Fe}^{2+}, \mathrm{Na}^{+}\right.$, and $\left.\mathrm{K}^{+}\right)$at $5 \mathrm{mM}$ on enzymatic activity was investigated by the standard enzyme assay (Table 3 ). The activity of $\mathrm{HSPH}_{\mathrm{ZZ}}$ was not significantly affected by $\mathrm{Mg}^{2+}, \mathrm{Ni}^{2+}, \mathrm{Ca}^{2+}, \mathrm{Mn}^{2+}, \mathrm{K}^{+}, \mathrm{Na}^{+}$, or the chelator EDTA $(0.5 \mathrm{mM}$ and $5 \mathrm{mM})$, indicating that this enzyme was not a metalloprotein. However, $\mathrm{Cu}^{2+}, \mathrm{Co}^{2+}, \mathrm{Zn}^{2+}$, and $\mathrm{Fe}^{2+}$ significantly inhibited enzyme activity. As shown in Table 4, the effects of methanol, acetone, formaldehyde, Dimethylformamide (DMF), chloroform, and toluene at 20\% $(v / v)$ also markedly inhibited enzyme activity, while more than $90 \%$ of $\mathrm{HSPH}_{\mathrm{ZZ}}$ activity was retained after incubation with DMSO. Incubation with Triton X-100, Span 20, and Span 40 at $1 \%(w / v)$ reduced the hydroxylase activity by less than $50 \%$ (Table 4). The enzyme activity was not reduced by adding Tween 20 , Tween 40 , or Tween 80 at $1 \%(w / v)$.

Table 3. Effect of various metals on the enzymatic activity of $\mathrm{HSPH}_{\mathrm{ZZ}}{ }^{\mathrm{a}}$.

\begin{tabular}{ccc}
\hline Metals or Inhibitors & Concentration & Relative Activity (\%) \\
\hline $\mathrm{None}^{2+}$ & - & 100 \\
$\mathrm{Mg}^{2+}$ & $5 \mathrm{mM}$ & $86 \pm 3$ \\
$\mathrm{Zn}^{2+}$ & $5 \mathrm{mM}$ & $27 \pm 2$ \\
$\mathrm{Cu}^{2+}$ & $5 \mathrm{mM}$ & $23 \pm 1$ \\
$\mathrm{Ca}^{2+}$ & $5 \mathrm{mM}$ & $92 \pm 2$ \\
$\mathrm{Mn}^{2+}$ & $5 \mathrm{mM}$ & $87 \pm 4$ \\
$\mathrm{Fe}^{2+}$ & $5 \mathrm{mM}$ & $13 \pm 2$ \\
$\mathrm{Ni}^{2+}$ & $5 \mathrm{mM}$ & $81 \pm 3$ \\
$\mathrm{Co}^{2+}$ & $5 \mathrm{mM}$ & $31 \pm 3$ \\
$\mathrm{~K}^{+}$ & $5 \mathrm{mM}$ & $101 \pm 5$ \\
$\mathrm{Na}^{+}$ & $5 \mathrm{mM}$ & $98 \pm 2$ \\
$\mathrm{EDTA}$ & $0.5 \mathrm{mM}$ & $79 \pm 2$ \\
& $5 \mathrm{mM}$ & $85 \pm 2$ \\
\hline
\end{tabular}

a The values are means of three independent experiments. 
Table 4. Effect of various organic solvent and detergents on the activity of $\mathrm{HSPH}_{\mathrm{ZZ}}{ }^{\mathrm{a}}$.

\begin{tabular}{ccc}
\hline Metals or Inhibitors & Concentration (\%) & Relative Activity (\%) \\
\hline None & - & 100 \\
Methanol & $20(v / v)$ & $61 \pm 2$ \\
Acetone & $20(v / v)$ & $59 \pm 4$ \\
Chloroform & $20(v / v)$ & $33 \pm 2$ \\
Formaldehyde & $20(v / v)$ & $23 \pm 3$ \\
Toluene & $20(v / v)$ & $28 \pm 5$ \\
DMF & $20(v / v)$ & $65 \pm 2$ \\
DMSO & $20(v / v)$ & $93 \pm 5$ \\
Tween 20 & $1(w / v)$ & $86 \pm 5$ \\
Tween 40 & $1(w / v)$ & $110 \pm 4$ \\
Tween 80 & $1(w / v)$ & $91 \pm 1$ \\
Triton X-100 & $1(w / v)$ & $48 \pm 3$ \\
Span 20 & $1(w / v)$ & $12 \pm 4$ \\
Span 40 & $1(w / v)$ & $17 \pm 5$ \\
\hline
\end{tabular}

${ }^{a}$ The values are means of three independent experiments.

\subsection{2,5-DHP Production from HSP by $\mathrm{HSPH}_{\mathrm{ZZ}}$ under Optimum Conditions}

The production of 2,5-DHP from HSP by $\mathrm{HSPH}_{\mathrm{ZZ}}$ was investigated under optimum conditions (at $30{ }^{\circ} \mathrm{C}$ and $\mathrm{pH} 8.5$ in $20 \mathrm{mM}$ Tris- $\mathrm{HCl}$ buffer), with $\mathrm{HSPH}_{\mathrm{ZZ}}$ at a concentration of $1 \mu \mathrm{M}$ in the standard enzyme assay. The enzyme produced 2,5-DHP $(85.3 \mathrm{mg} / \mathrm{L})$ in $40 \mathrm{~min}$ with a conversion of $74.9 \%(w / w)$ (Figure 5). The 2,5-DHP decomposed over time in the reaction solution, indicating that it was unstable and probably sensitive to oxidation. The amount of HSP consumed in the enzyme reaction in $40 \mathrm{~min}$ was $161 \mathrm{mg} / \mathrm{L}(0.83 \mathrm{mM})$ out of the initial $200 \mathrm{mg} / \mathrm{L}$. Based on the conversion stoichiometry, the estimated amount of 2,5-DHP produced was $92.1 \mathrm{mg} / \mathrm{L}$, corresponding to a conversion yield of $80.9 \%$. Thus, the amount of 2,5-DHP lost during the reaction was $6.8 \mathrm{mg} / \mathrm{L}$ (amount produced minus amount detected). The rate of HSP catalysis by $\mathrm{HSPH}_{\mathrm{ZZ}}$ was higher than that of the HSP hydroxylase from A. tumefaciens $\mathrm{S} 33\left(69.7 \%\right.$ at $35^{\circ} \mathrm{C}$ and $\mathrm{pH} 8.0$ in $\left.50 \mathrm{~min}\right)$ [28]. These results demonstrated that $\mathrm{HSPH}_{\mathrm{ZZ}}$ has strong activity to produce 2,5-DHP HSP, making it a potential candidate for enzymatic transformation of HSP into 2,5-DHP in commercial applications.

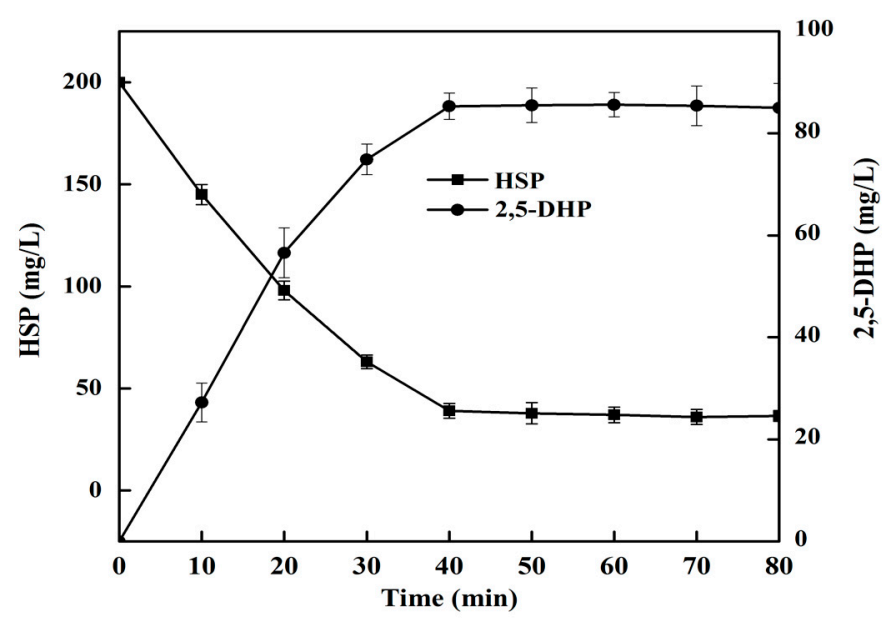

Figure 5. Time course of 2,5-DHP (circles) production from HSP (boxes) under the optimum condition. The reactions were performed in $20 \mathrm{mM}$ Tris- $\mathrm{HCl}$ buffer ( $\mathrm{pH}$ 8.5) containing $10 \mathrm{mM}$ FAD, $1.0 \mu \mathrm{M}$ enzyme, $200 \mathrm{mg} / \mathrm{L} \mathrm{HSP}$, and $0.5 \mathrm{mM} \mathrm{NADH}$ at $30{ }^{\circ} \mathrm{C}$ for $80 \mathrm{~min}$. The values are means of three independent experiments. 


\section{Experimental Section}

\subsection{Chemicals, Strains, and Plasmids}

Using nicotine as the sole source of carbon and nitrogen, Pseudomonas sp. ZZ-5 was isolated from soil samples obtained from a field under continuous tobacco cropping in Henan, P.R. China. The strain was cultured in nicotine medium containing (per liter) $22.8 \mathrm{~g} \mathrm{~K}_{2} \mathrm{HPO}_{4} \cdot 3 \mathrm{H}_{2} \mathrm{O}, 6.8 \mathrm{~g} \mathrm{KH}_{2} \mathrm{PO}_{4}$, $0.5 \mathrm{~g} \mathrm{MgSO}_{4} \cdot 7 \mathrm{H}_{2} \mathrm{O}$, and $1 \mathrm{~mL}$ trace elements solution. The trace elements solution contained $0.05 \mathrm{~g} \mathrm{CaCl}_{2} \cdot 2 \mathrm{H}_{2} \mathrm{O}, 0.05 \mathrm{~g} \mathrm{CuCl}_{2} \cdot 2 \mathrm{H}_{2} \mathrm{O}, 0.008 \mathrm{~g} \mathrm{MnSO}_{4} \cdot \mathrm{H}_{2} \mathrm{O}, 0.004 \mathrm{~g} \mathrm{FeSO}_{4} \cdot 7 \mathrm{H}_{2} \mathrm{O}, 0.1 \mathrm{~g} \mathrm{ZnSO}_{4}$, $0.1 \mathrm{~g} \mathrm{Na}_{2} \mathrm{MoO}_{4} \cdot 2 \mathrm{H}_{2} \mathrm{O}$, and $0.05 \mathrm{~g} \mathrm{Na}_{2} \mathrm{WO}_{4} \cdot 2 \mathrm{H}_{2} \mathrm{O}[9,29]$. The plasmid pET22b and E. coli strain BL21-CodonPlus (DE3)-RIL were respectively bought from Novagen (Madison, WI, USA) and Stratagene (La Jolla, CA, USA). Pyrobest DNA polymerase, restriction enzymes, and the DNA ligation kit were purchased from Takara Biotechnology (Dalian, China). The DEAE-anion exchange column, phenyl-sepharose column, nickel columns, and Superdex 200 gel filtration columns were from GE Healthcare (Buckinghamshire, UK), and 2,5-DHP was purchased from SynChem OHG (Altenburg, Germany). Chromatographic-grade succinic acid was purchased from J\&K Scientific Ltd. (Beijing, China). We obtained HSP from Professor Hongzhi Tang at Shanghai Jiao Tong University. All other chemicals were of analytical grade and were obtained from Sangon (Shanghai, China).

\subsection{Purification of $H S P H_{Z Z}$}

Cells of Pseudomonas sp. ZZ-5 (approx. $15 \mathrm{~g}$ ) were suspended in $50 \mathrm{mM}$ Tris-HCl buffer ( $\mathrm{pH}$ 8.0) and disrupted by sonication $(40 \mathrm{kHz}, 80-100 \mathrm{~W})$. The supernatant was subjected to ammonium sulfate fractionation and yielded a precipitate at $50-70 \%$ saturation with $\left(\mathrm{NH}_{4}\right)_{2} \mathrm{SO}_{4}$. The mixture was allowed to stand overnight, and then the precipitate was collected by centrifugation at $20,000 \times g$ for $20 \mathrm{~min}$. The precipitate was loaded onto a DEAE-anion exchange column $\left(1 \times 20 \mathrm{~cm}^{2}\right.$, GE Healthcare $)$ equilibrated with $50 \mathrm{mM}$ Tris-HCl buffer ( $\mathrm{pH}$ 8.0). The column was washed with a linear salt gradient from $50 \mathrm{mM}$ to $1 \mathrm{M} \mathrm{NaCl}$. The fractions containing the target protein were collected at $300-400 \mathrm{mM}$ and concentrated using a membrane with a 30-kDa MW cut off. The sample was applied to a phenyl-sepharose column $\left(1 \times 20 \mathrm{~cm}^{2}\right.$, GE Healthcare, Buckinghamshire, UK) equilibrated with $50 \mathrm{mM}$ Tris- $\mathrm{HCl}$ buffer containing $1.0 \mathrm{M}\left(\mathrm{NH}_{4}\right)_{2} \mathrm{SO}_{4}$. The target protein was eluted at an $\left(\mathrm{NH}_{4}\right)_{2} \mathrm{SO}_{4}$ concentration of $0.8 \mathrm{M}$, desalted, and then enriched. Finally, the protein mixture was loaded onto a Superdex 200 gel filtration column (GE Healthcare, Buckinghamshire, UK), which was pre-equilibrated with $50 \mathrm{mM}$ Tris- $\mathrm{HCl}$ ( $\mathrm{pH} 8.0$ ) containing $200 \mathrm{mM} \mathrm{NaCl}$. The fraction size was $1 \mathrm{~mL}$ (flow rate, $1 \mathrm{~mL} / \mathrm{min}$ ). The peak fractions were determined by assaying enzymatic activity under standard conditions. The fractions with HSP hydroxylase activity were collected and analyzed by SDS-PAGE. The protein concentration was determined using the Bradford method.

\subsection{Enzymatic Activity Assay}

The activity of HSP hydroxylase was determined using the method of Tang et al. [23,30]. The standard reaction mixture, containing $10 \mathrm{mM}$ FAD, $1 \mathrm{mM}$ HSP, $0.5 \mathrm{mM} \mathrm{NADH}$, and $20 \mathrm{mM}$ Tris-HCl buffer ( $\mathrm{pH}$ 8.5), was preincubated for $2 \mathrm{~min}$ and then the reaction was started by adding the purified enzyme. The enzymatic activity was measured at $30{ }^{\circ} \mathrm{C}$ for $30 \mathrm{~min}$ and the production of 2,5-DHP was monitored by liquid chromatography-mass spectrometry (LC-MS) analysis. The reaction products were characterized by an electron spray ionization (ESI) source on an AB Sciex Triple Quad 5500 mass spectrometer with an Agilent 1290 infinity LC system for UHPLC. The UHPLC analyses were performed with a ZORBAX Eclipse Plus-C18 column (column size, $150 \times 4.6 \mathrm{~mm}$; particle size, $5 \mu \mathrm{m}$; Agilent, Palo Alto, CA, USA) and a mobile phase of methanol:1 $\mathrm{mM}$ acetic acid $(25: 75, v / v$; flow rate, $0.5 \mathrm{~mL} / \mathrm{min}$ ).

One unit of hydroxylase activity was defined as the amount of enzyme releasing $1 \mathrm{~mol} 2,5$-DHP per min under standard conditions. Measurements were corrected for background hydrolysis in the absence of enzyme. 


\subsection{N-Terminal Amino Acid Sequence of $\mathrm{HSPH}_{\mathrm{ZZ}}$}

After analysis by SDS-PAGE, the target protein was transferred onto a polyvinylidene difluoride membrane Hybond-P (Amersham Pharmacia Biotech, Orsay, France) and visualized with Coomassie brilliant blue staining. Then, the corresponding bands were excised, and the $\mathrm{N}$-terminal and internal partial amino acid sequences of the protein were determined by the Sangon.

\subsection{Gene Cloning and Construction of Expression Plasmid}

The N-terminal amino acid sequence of $\mathrm{HSPH}_{\mathrm{ZZ}}$ was used to search the GenBank database, and the sequences retrieved were used to design primers to amplify $\mathrm{HSPH}_{\mathrm{ZZ}}$. The gene encoding $\mathrm{HSPH}_{\mathrm{ZZ}}$ was amplified using PCR with the following primers: forward, $5^{\prime}$-GCACATATGAGCGG ACATCAGGATGTCATC- ${ }^{\prime}$, and reverse, $5^{\prime}$-GCGGTCGACCAACTATGTCTGCATTAATTGCGG- $3^{\prime}$ (NdeI and SalI sites underlined, respectively). Genomic DNA was extracted from Pseudomonas sp. ZZ-5 using a Gentra Puregene Yeast/bact. Kit B following the manufacturer's instructions (Qiagen, Valencia, CA, USA) and used as the template for PCR amplification. The PCR conditions were as follows: $94{ }^{\circ} \mathrm{C}$ for $1 \mathrm{~min}, 6{ }^{\circ} \mathrm{C}$ for $1 \mathrm{~min}, 72{ }^{\circ} \mathrm{C}$ for $2 \mathrm{~min}$, and a final extension at $72{ }^{\circ} \mathrm{C}$ for $10 \mathrm{~min}$. The PCR product was subsequently purified, digested with NdeI and SalI, and then cloned into pET22b to generate $\mathrm{pET15b}-\mathrm{HSPH} \mathrm{ZZ}_{\mathrm{Z}}$. The DNA insert was sequenced to confirm that no unintended mutation had occurred.

\subsection{Expression and Purification of Recombinant $\mathrm{HSPH}_{\mathrm{ZZ}}$}

The plasmid pET15b-HSPH ${ }_{Z Z}$ was transformed into E. coli BL21-Codon Plus (DE3)-RIL cells for gene expression. The transformed cells were grown in LB broth containing $100 \mathrm{mg} / \mathrm{L}$ ampicillin and $34 \mathrm{mg} / \mathrm{L}$ chloramphenicol at $37{ }^{\circ} \mathrm{C}$ and with shaking at $150 \mathrm{rpm}$. When the $\mathrm{OD}_{600}$ value of the cultures reached $0.4-0.6$, isopropyl- $\beta$-D-thiogalactopyranoside (IPTG) was added to a final concentration of $0.2 \mathrm{mM}$ to induce gene expression. After further culture for $6 \mathrm{~h}$ at $30^{\circ} \mathrm{C}$, the cells were harvested by centrifugation, resuspended in buffer A $(50 \mathrm{mM}$ Tris- $\mathrm{HCl}, \mathrm{pH} 7.8,200 \mathrm{mM}$ $\mathrm{NaCl})$ and disrupted by sonication. Cell debris was removed by centrifugation at $20,000 \times g$ at $4{ }^{\circ} \mathrm{C}$ for $20 \mathrm{~min}$. The soluble fraction was loaded onto a $\mathrm{Ni}^{2+}$-NTA agarose column (GE Healthcare, Buckinghamshire, UK) pre-equilibrated with buffer A. After washing with buffer containing $60 \mathrm{mM}$ imidazole, the enzymes were eluted with buffer B $(20 \mathrm{mM}$ Tris- $\mathrm{HCl}, \mathrm{pH} 7.8,500 \mathrm{mM} \mathrm{NaCl}, 300 \mathrm{mM}$ imidazole). The purified protein was analyzed by SDS-PAGE (12\% polyacrylamide) and the protein concentration was determined using the Bradford method.

\subsection{Catalytic Properties of Recombinant $\mathrm{HSPH}_{\mathrm{ZZ}}$}

The optimum $\mathrm{pH}$ and temperature for recombinant $\mathrm{HSPH}_{\mathrm{ZZ}}$ activity were determined using the standard enzymatic assay and LC-MS (AB Sciex, Framingham, MA, USA). The effect of $\mathrm{pH}$ on hydroxylase activity was examined at $30^{\circ} \mathrm{C}$ within the $\mathrm{pH}$ range of 5.5 to 10.0 . The effect of temperature (from $5{ }^{\circ} \mathrm{C}$ to $45^{\circ} \mathrm{C}$ ) on enzymatic activity was investigated at $\mathrm{pH}$ 8.5. The effects of several different metal ions, organic solvents, and detergents on the activity of $\mathrm{HSPH}_{\mathrm{ZZ}}$ were determined by adding each metal salt $(5 \mathrm{mM})$, organic solvent $(20 \%, v / v)$, and detergent $(1 \%, v / v)$ to the standard assay solution.

\section{Conclusions}

We have cloned a novel HSP hydroxylase from Pseudomonas sp. ZZ-5 $\left(\mathrm{HSPH}_{\mathrm{ZZ}}\right)$, and expressed it in a bacterial cell system. The recombinant $\mathrm{HSPH}_{Z Z}$ showed strong enzymatic activity to convert HSP to 2,5-DHP in the presence of NADH and FAD. The effects of temperature, $\mathrm{pH}$, and concentrations of substrate and enzyme for 2,5-DHP production were optimized. Under optimum conditions, $\mathrm{HSPH}_{\mathrm{ZZ}}$

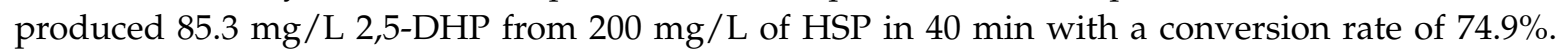
These results demonstrate that $\mathrm{HSPH}_{\mathrm{ZZ}}$ could be a potential candidate for the enzymatic synthesis of 2,5-DHP in pharmaceutical applications. 
Supplementary Materials: The following are available online at www.mdpi.com/2073-4344/7/9/257/s1, Figure S1: LC-MS profiles of the reaction catalyzed by $\mathrm{HSPH}_{Z Z}$. Mass spectra of products succinic acid $(\mathrm{m} / z$ 117.15) (a), 2,5-DHP $(m / z$ 110.18) (b) and substrate HSP $(m / z$ 194.04) (c), respectively. Negatively charged ions were detected; Figure S2: Multiple sequence alignment for $\mathrm{HSPH}_{\mathrm{ZZ}}$ and its homologs. An alignment was carried out using Clustal $\mathrm{W}$ program with manual adjusting. The conserved GADGA motif is in shallow. Abbreviation: $\mathrm{HSPH}_{Z Z}$ from Pseudomonas sp. ZZ-5; WP_013973865.1 from Pseudomonas putida S16; WP_031302470.1 from Pseudomonas sp. EGD-AK9; WP_064613869.1 from Pseudomonas sp. JY-Q; WP_035209888.1 from Agrobacterium tumefaciens S33; Figure S3: Thermal stability (A) and pH stability (B) of HSPHZZ. A. Thermal stability of HSPHZZ. The residual enzyme activity was measured after incubation of the purified enzyme at $30{ }^{\circ} \mathrm{C}$ (triangles), $35^{\circ} \mathrm{C}$ (boxes), and $40^{\circ} \mathrm{C}$ (diamonds), respectively. B. pH stability of the enzyme at pHs ranging from 5.5 to 10 was measured for $30 \mathrm{~min}$ at $30^{\circ} \mathrm{C}$. The values are means of three independent experiments. Table S1: Purification of the recombinant $\mathrm{HSPH}_{\mathrm{ZZ}}$ from Pseudomonas sp. ZZ-5.

Acknowledgments: This work was supported by grants from the Henan Province Foreign Cooperation Projects (152106000058), key scientific and technological project of Henan Province (162102210061) and the National Natural Science Foundation of China (21406210).

Author Contributions: T.W. designed and performed the experiments, analyzed the data and prepared the manuscript. J.Z., Y.Z., H.T. and S.H. assisted in data analysis. D.M. performed experiments, analyzed the data and assisted in manuscript preparation. All authors read and approved the final manuscript.

Conflicts of Interest: The authors declare no conflict of interest.

\section{References}

1. Benowitz, N.L. Nicotine addiction. N. Engl. J. Med. 2010, 362, 2295-2303. [CrossRef] [PubMed]

2. Hecht, S.S. Tobacco smoke carcinogens and lung cancer. J. Natl. Cancer Inst. 1999, 91, 1194-1210. [CrossRef] [PubMed]

3. Civilini, M.; Domenis, C.; Sebastianutto, N.; de Bertoldi, M. Nicotine decontamination of tobacco agro-industrial waste and its degradation by micro-organisms. Waste Manag. Res. 1997, 15, 349-358. [CrossRef]

4. Novotny, T.E.; Zhao, F. Consumption and production waste: Another externality of tobacco use. Tob. Control 1999, 8, 75-80. [CrossRef] [PubMed]

5. Seckar, J.A.; Stavanja, M.S.; Harp, P.R.; Yi, Y.; Garner, C.D.; Doi, J. Environmental fate and effects of nicotine released during cigarette production. Environ. Toxicol. Chem. 2008, 27, 1505-1514. [CrossRef] [PubMed]

6. Wang, J.H.; He, H.Z.; Wang, M.Z.; Wang, S.; Zhang, J.; Wei, W.; Xu, H.X.; Lu, Z.M.; Shen, D.S. Bioaugmentation of activated sludge with Acinetobacter sp. TW enhances nicotine degradation in a synthetic tobacco wastewater treatment system. Bioresour. Technol. 2013, 142, 445-453. [CrossRef] [PubMed]

7. Zhong, W.; Zhu, C.; Shu, M.; Sun, K.; Zhao, L.; Wang, C.; Ye, Z.; Chen, J. Degradation of nicotine in tobacco waste extract by newly isolated Pseudomonas sp. ZUTSKD. Bioresour. Technol. 2010, 101, 6935-6941. [CrossRef] [PubMed]

8. Ruan, A.D.; Min, H.; Zhu, W. Studies on biodegradation of nicotine by Arthrobacter sp. strain HF-2. J. Environ. Sci. Health B 2006, 41, 1159-1170. [CrossRef] [PubMed]

9. Wang, S.N.; Xu, P.; Tang, H.Z.; Meng, J.; Liu, X.L.; Huang, J.; Chen, H.; Du, Y.; Blankespoor, H.D. Biodegradation and detoxification of nicotine in tobacco solid waste by a Pseudomonas sp. Biotechnol. Lett. 2004, 26, 1493-1496. [CrossRef] [PubMed]

10. Wang, M.Z.; Yang, G.Q.; Min, H.; Lv, Z.M. A novel nicotine catabolic plasmid pMH1 in Pseudomonas sp. strain HF-1. Can. J. Microbiol. 2009, 55, 228-233. [CrossRef] [PubMed]

11. Qiu, J.G.; Ma, Y.; Wen, Y.Z.; Chen, L.S.; Wu, L.F.; Liu, W.P. Functional identification of two novel genes from Pseudomonas sp. strain HZN6 involved in the catabolism of nicotine. Appl. Environ. Microbiol. 2012, 78, 2154-2160. [CrossRef] [PubMed]

12. Meng, X.J.; Lu, L.L.; Gu, G.F.; Xiao, M. A novel pathway for nicotine degradation by Aspergillus oryzae 112822 isolated from tobacco leaves. Res. Microbiol. 2010, 161, 626-633. [CrossRef] [PubMed]

13. Qiu, J.G.; Li, N.; Lu, Z.M.; Yang, Y.J.; Ma, Y.; Niu, L.L.; He, J.; Liu, W.P. Conversion of nornicotine to 6-hydroxy-nornicotine and 6-hydroxy-myosmine by Shinella sp. strain HZN7. Appl. Microbiol. Biotechnol. 2016, 100, 10019-10029. [CrossRef] [PubMed]

14. Wang, M.Z.; Yang, G.Q.; Wang, X.; Yao, Y.L.; Min, H.; Lu, Z.M. Nicotine degradation by two novel bacterial isolates of Acinetobacter sp. TW and Sphingomonas sp. TY and their responses in the presence of neonicotinoid insecticides. World J. Microbiol. Biotechnol. 2011, 27, 1633-1640. [CrossRef] 
15. Enamorado, M.F.; Ondachi, P.W.; Comins, D.L. A five-step synthesis of (S)-macrostomine from $(S)$-nicotine. Org. Lett. 2010, 12, 4513-4515. [CrossRef] [PubMed]

16. Ondachi, P.W.; Comins, D.L. Synthesis of fused-ring nicotine derivatives from (S)-nicotine. J. Org. Chem. 2010, 75, 1706-1716. [CrossRef] [PubMed]

17. Kagarlitskii, A.D.; Iskakova, M.K.; Turmukhambetov, A.Z. Catalytic conversion of nicotine into nicotinonitrile-a pharmaceutical intermediate product. Pharm. Chem. J. 2002, 36, 26-27. [CrossRef]

18. Fananas, F.J.; Arto, T.; Mendoza, A.; Rodriguez, F. Synthesis of 2,5-dihydropyridine derivatives by gold-catalyzed reactions of $\beta$-ketoesters and propargylamines. Org. Lett. 2011, 13, 4184-4187. [CrossRef] [PubMed]

19. Abbas, H.A.S.; El Sayed, W.A.; Fathy, N.M. Synthesis and antitumor activity of new dihydropyridine thioglycosides and their corresponding dehydrogenated forms. Eur. J. Med. Chem. 2010, 45, 973-982. [CrossRef] [PubMed]

20. Briede, J.; Stivrina, M.; Vigante, B.; Stoldere, D.; Duburs, G. Acute effect of antidiabetic 1,4-dihydropyridine compound cerebrocrast on cardiac function and glucose metabolism in the isolated, perfused normal rat heart. Cell Biochem. Chem. Funct. 2008, 26, 238-245. [CrossRef] [PubMed]

21. Kappe, C.O. Biologically active dihydropyrimidones of the Biginelli-type-A literature survey. Eur. J. Med. Chem. 2000, 35, 1043-1052. [CrossRef]

22. Hilgeroth, A. Dimeric 4-aryl-1,4-dihydropyridines: Development of a third class of nonpeptidic HIV-1 protease inhibitors. Mini-Rev. Med. Chem. 2002, 2, 235-245. [CrossRef] [PubMed]

23. Tang, H.Z.; Yao, Y.X.; Zhang, D.K.; Meng, X.Z.; Wang, L.J.; Yu, H.; Ma, L.Y.; Xu, P. A novel NADH-dependent and FAD-containing hydroxylase is crucial for nicotine degradation by Pseudomonas putida. J. Biol. Chem. 2011, 286, 39179-39187. [CrossRef] [PubMed]

24. Wang, S.; Huang, H.; Xie, K.; Xu, P. Identification of nicotine biotransformation intermediates by Agrobacterium tumefaciens strain S33 suggests a novel nicotine degradation pathway. Appl. Microbiol. Biotechnol. 2012, 95, 1567-1578. [CrossRef] [PubMed]

25. Eppink, M.H.; Schreuder, H.A.; Van Berkel, W.J. Identification of a novel conserved sequence motif in flavoprotein hydroxylases with a putative dual function in FAD/NAD $(\mathrm{P}) \mathrm{H}$ binding. Protein Sci. 1997, 6, 2454-2458. [CrossRef] [PubMed]

26. Li, H.L.; Xie, K.B.; Huang, H.Y.; Wang, S.N. 6-Hydroxy-3-Succinoylpyridine hydroxylase catalyzes a central step of nicotine degradation in Agrobacterium tumefaciens S33. PLoS ONE 2014, 9, e103324. [CrossRef] [PubMed]

27. Wei, T.; Huang, S.; Zang, J.; Jia, C.X.; Mao, D.B. Cloning, expression and characterization of a novel fructosyltransferase from Aspergillus oryzae ZZ-01 for the synthesis of sucrose 6-acetate. Catalysts 2016, 6, 67. [CrossRef]

28. Yang, Z.; Pan, W.B. Ionic liquids: Green solvents for nonaqueous biocatalysis. Enzym. Microb. Technol. 2005, 37, 19-28. [CrossRef]

29. Wang, S.N.; Liu, Z.; Tang, H.Z.; Meng, J.; Xu, P. Characterization of environmentally friendly nicotine degradation by Pseudomonas putida biotype A strain S16. Microbiology 2007, 153, 1556-1565. [CrossRef] [PubMed]

30. Yu, H.; Hausinger, R.P.; Tang, H.Z.; Xu, P. Mechanism of the 6-Hydroxy-3-succinoyl-pyridine 3-monooxygenase flavoprotein from Pseudomonas putida S16. J. Biol. Chem. 2014, 289, 29158-29170. [CrossRef] [PubMed]

(C) 2017 by the authors. Licensee MDPI, Basel, Switzerland. This article is an open access article distributed under the terms and conditions of the Creative Commons Attribution (CC BY) license (http://creativecommons.org/licenses/by/4.0/). 